\title{
Ecological and pathological factors related to trace metal concentrations in harbour porpoises Phocoena phocoena from the North Sea and adjacent areas
}

\author{
Krishna Das ${ }^{1,2, *}$, Ursula Siebert ${ }^{2}$, Michaël Fontaine ${ }^{1}$, Thierry Jauniaux ${ }^{3}$, \\ Ludo Holsbeek $^{4}$, Jean-Marie Bouquegneau ${ }^{1}$ \\ ${ }^{1}$ Marine Research Center (MARE), Laboratory for Oceanology, B6c, Liège University, 4000 Liège, Belgium \\ ${ }^{2}$ Forschungs- und Technologiezentrum Westküste, Christian-Albrechts-Universität Kiel, Werftstraße 6, 25761 Büsum, Germany \\ ${ }^{3}$ Department of Pathology, Faculty of Veterinary Medicine, B43 Liège University, 4000 Liège, Belgium \\ ${ }^{4}$ Laboratory for Ecotoxicology, Free University of Brussels, 1050 Brussels, Belgium
}

\begin{abstract}
There is growing concern about the health status of the harbour porpoise Phocoena phocoena in the North Sea and adjacent areas. The interaction between toxicological results $(\mathrm{Zn}, \mathrm{Cd}, \mathrm{Cu}$, $\mathrm{Fe}, \mathrm{Se}, \mathrm{Hg})$, stable isotope data $\left(\delta^{13} \mathrm{C}\right.$ and $\left.\delta^{15} \mathrm{~N}\right)$ and the most common pathological findings, namely emaciation and lesions of the respiratory system, were investigated in 132 porpoises collected along the coasts of northern France, Belgium, Germany, Denmark, Iceland and Norway between 1994 and 2001. The body condition of harbour porpoises stranded on the French, Belgian and German coasts was poor compared to that of by-catch individuals from Iceland and Norway, as reflected by blubber thickness and hepatic to total body-mass ratio. High Zn and Hg concentrations were observed in some porpoises collected along the southern North Sea coast compared to by-catch individuals from Iceland, Norway and the Baltic Sea. Increasing Zn levels were observed with deteriorating health condition (emaciation and bronchopneumonia), while $\mathrm{Hg}$ increases were not significant. The increases were not related to shrinking liver mass which remained unchanged. These observations indicate a general redistribution of trace metals within the organs (muscles and blubber to liver), as a result of protein and lipid catabolism. Muscle $\delta^{13} \mathrm{C}$ and $\delta^{15} \mathrm{~N}$ values remained unchanged with deteriorating body condition. Cd concentrations were associated only with age and low $\delta^{15} \mathrm{~N}$ values, indicating that high $\mathrm{Cd}$ concentrations in Iceland and Norway porpoises may be partly diet-related, i.e. a result of $\mathrm{Cd}$ contaminated prey.
\end{abstract}

KEY WORDS: North Sea · Marine mammals · Stable isotopes · Heavy metals · Harbour porpoise · Health status

\section{INTRODUCTION}

There is a growing concern about the long-term viability of harbour porpoise Phocoena phocoena populations in the North Sea and adjacent areas. Since 1998, the southern North Sea regions, including the northern French, Belgian and Dutch coasts have been characterised by an increased number of stranded marine mammals, in particular the harbour porpoise
(Jauniaux et al. 2002). Marine mammals are the final trophic link in the southern North Sea (Das et al. $2003 \mathrm{~b}$ ), and therefore a potential impact of pollutants on their health is of concern. Several investigations have attempted to evaluate organic contaminant effects at ambient environmental levels (e.g. Reijnders 1986, Aguilar \& Borrell 1994, de Swart et al. 1994, De Guise et al. 1995, Jepson et al. 1999); fewer studies have tried to link marine mammal health and metal levels 
(Hyvärinen \& Sipilä 1984, Siebert et al. 1999, Bennet et al. 2001). While zinc ( $\mathrm{Zn})$, iron (Fe), copper $(\mathrm{Cu})$ and selenium (Se) are key components associated with hundreds of metalloenzymes, mercury (Hg) and cadmium $(\mathrm{Cd})$ have no vital functions in mammals and may cause immunosuppression in various species (Zelikoff \& Tomas 1998). However, a clear cause-effect relationship between the residue levels of contaminants in marine mammals and the observed effects has been demonstrated in only a few studies (Reijnders \& Aguilar 2002). The main reasons for the lack of proof of the impact of pollutants on marine mammals are the difficulty of experimenting in laboratory conditions and the frequent occurrence of confounding factors that hamper the establishment of cause-effect relationships (Reijnders \& Aguilar 2002). An alternative to undesirable experimental manipulation of marine mammals is systematic post-mortem investigations to establish the health status of stranded and by-catch animals coupled with pollutant analysis (Jepson et al. 1999, Siebert et al. 1999, Bennet et al. 2001, Anan et al. 2002).

Heavy metal concentrations in marine mammals depend not only on environmental contamination, but also on several biological and ecological factors such as age, body condition or diet (Caurant et al. 1994, Law 1996, Bennet et al. 2001, Das et al. 2002). Diet studies often comprise stomach-content analysis or field observations (Santos \& Pierce 2003). In marine mammals, the use of naturally occurring stable isotope ratios of carbon and nitrogen $\left({ }^{13} \mathrm{C} /{ }^{12} \mathrm{C}\right.$ and ${ }^{15} \mathrm{~N} /{ }^{14} \mathrm{~N}$; in delta notation, $\delta^{13} \mathrm{C}$ and $\delta^{15} \mathrm{~N}$ ) has recently provided interesting insights into their feeding ecology (e.g. Hobson \& Welch 1992, Abend \& Smith 1995, Hobson et al. 1996, Smith et al. 1996, Burns et al. 1998, Lesage et al. 2001, Das et al. 2003b). The use of $\delta^{13} \mathrm{C}$ and $\delta^{15} \mathrm{~N}$ measurements is based on the assumption that the isotopic composition of an animal reflects that of its prey (reviewed by Gannes et al. 1998, Kelly 2000). Stable isotope analysis has been used previously to provide a continuous variable with which to assess both trophic level (Michener \& Schell 1994, Hobson et al. 1995, Das et al. 2003b) and transfer of contaminants (Kidd et al. 1995, Das et al. 2000, 2003a).

Using an ordinal logistic regression, the present study investigated the potential relationship between the health status of the harbour porpoise and trace metal concentrations ( $\mathrm{Zn}, \mathrm{Cd}, \mathrm{Cu}, \mathrm{Fe}, \mathrm{Se}, \mathrm{Hg})$, in the tissues of 132 harbour porpoises from northern France, Belgium, Germany (North and Baltic Seas), Denmark, Iceland and Norway by combining toxicological results and the most common pathological findings, namely emaciation and lesions of the respiratory system. This indirect approach was intended to test the prediction that increased exposure to toxic metals lowers the resistance to disease of harbour porpoises off European coasts. Furthermore, we compared stable isotope ratios in the muscles of porpoises displaying good, moderate and poor body conditions. Nutritional stress and starvation may modify stable isotope ratios in birds and mammals, raising the question of the suitability of these isotopes for studying the feeding ecology of debilitated marine mammals (Hobson \& Clark 1992, Gannes et al. 1998). The relationship between $\delta^{13} \mathrm{C}$ and $\delta^{15} \mathrm{~N}$ measurements and trace metal concentrations was examined for evidence of diet transfer or biomagnification. Finally, discriminant analysis was used to assess the ability of trace element (hepatic $\mathrm{Zn}, \mathrm{Cd}, \mathrm{Fe}$, $\mathrm{Cu}, \mathrm{Se}, \mathrm{Hg}$ ) and stable isotope (muscle $\delta^{13} \mathrm{C}$ and $\delta^{15} \mathrm{~N}$ ) values to discriminate among the different locations, i.e. northern France and Belgium, Germany (North and Baltic Seas), Denmark (Skagerrak, Kattegat and Baltic Sea), Iceland and Norway.

\section{MATERIALS AND METHODS}

Sample collection and storage. Liver, kidney and muscle were collected from 132 harbour porpoises stranded along the northern France, Belgian and German coasts between 1994 and 2001 (sample numbers in Table 1). Tissue samples were similarly collected from harbour porpoises caught incidentally (by-catch) in fishing nets along the coasts of Germany (Baltic Sea), Denmark (Skagerrat, Kattegat and Baltic Seas), Iceland and Norway. Post-mortem investigations were performed according to standard protocol (Kuiken \& Hartmann 1993). The samples of liver, kidney and muscle were stored at $-20^{\circ} \mathrm{C}$ until analysis.

Age was determined by quantification of growthlayer groups from analyses of decalcified tooth sections (Lockyer 1995) of 85 porpoises. The liver and left kidney mass was available for 78 and 32 porpoises respectively.

Pathology. The nutritional status (or body condition) was judged on the basis of blubber thickness, measured at 4 different locations (sternal, caudodorsal, caudolateral and caudoventral to the dorsal fin) and on the state of muscles and was divided into 3 categories: good, moderate, poor (i.e. emaciated), as previously described (Siebert et al. 1999, 2001, Jauniaux 2002). The lesions of the respiratory system were grouped into absence of lesions, mild (pulmonary oedema, pulmonary congestion, no nematode infestation, no pneumonia) and moderate-to-severe lesions (pulmonary oedema, pulmonary congestion, mild-to-severe nematode infestation and mild-to-severe pneumonia). Lesions of the respiratory tract were classified in a different way for porpoises from northern France and Belgium, and so were not included in this study. 
Table 1. Phocoena phocoena. Trace element ( $\mu \mathrm{g} \mathrm{g}^{-1}$ dry wt) concentrations in tissues of harbour porpoises from North Sea and adjacent areas. Mean (median) $\pm \mathrm{SD}$, range of concentrations (minimum-maximum); n: number of samples; nd: not determined

\begin{tabular}{|c|c|c|c|c|c|c|c|}
\hline & & $\begin{array}{c}\text { North Sea } \\
\text { Belgium and } \\
\text { northern France }\end{array}$ & $\begin{array}{l}\text { North Sea } \\
\text { Germany }\end{array}$ & $\begin{array}{l}\text { Baltic Sea } \\
\text { Germany }\end{array}$ & $\begin{array}{l}\text { North Sea } \\
\text { Denmark }\end{array}$ & $\begin{array}{l}\text { Atlantic } \\
\text { Iceland }\end{array}$ & $\begin{array}{l}\text { Atlantic } \\
\text { Norway }\end{array}$ \\
\hline \multirow[t]{3}{*}{ Zn } & Liver & $\begin{array}{c}234(163) \pm 172 \\
(40-684) \\
\mathrm{n}=49\end{array}$ & $\begin{array}{c}219(172) \pm 181 \\
(71-727) \\
\mathrm{n}=14\end{array}$ & $\begin{array}{c}135(120) \pm 56 \\
(78-242) \\
\mathrm{n}=9\end{array}$ & $\begin{array}{c}117(104) \pm 44 \\
(75-261) \\
n=17\end{array}$ & $\begin{array}{c}135(120) \pm 26 \\
(114-187) \\
n=11\end{array}$ & $\begin{array}{c}98(94) \pm 20 \\
(69-140) \\
n=21\end{array}$ \\
\hline & Kidney & $\begin{array}{c}107(101) \pm 27 \\
(68-201) \\
n=48\end{array}$ & $\begin{array}{c}103(99) \pm 26 \\
(69-157) \\
\mathrm{n}=12\end{array}$ & $\begin{array}{c}90(88) \pm 20 \\
(68-136) \\
n=9\end{array}$ & $\begin{array}{c}92(83) \pm 23 \\
(74-166) \\
n=15\end{array}$ & $\begin{array}{c}101(105) \pm 16 \\
(78-120) \\
n=11\end{array}$ & $\begin{array}{c}90(87) \pm 17 \\
(73-134) \\
n=20\end{array}$ \\
\hline & Muscle & $\begin{array}{c}74(65) \pm 33 \\
(24-193) \\
\mathrm{n}=51\end{array}$ & $\begin{array}{c}79(77) \pm 23 \\
(51-123) \\
n=13\end{array}$ & $\begin{array}{c}58(53) \pm 27 \\
(27-124) \\
n=9\end{array}$ & $\begin{array}{c}71(56) \pm 34 \\
(39-148) \\
n=15\end{array}$ & $\begin{array}{c}44(47) \pm 13 \\
(20-61) \\
\mathrm{n}=10\end{array}$ & $\begin{array}{c}44(39) \pm 26 \\
(19-149) \\
n=21\end{array}$ \\
\hline \multirow[t]{3}{*}{ Cd } & Liver & $\begin{array}{c}0.5(0.2) \pm 0.6 \\
(<0.05-2.5) \\
\mathrm{n}=49\end{array}$ & $\begin{array}{c}0.7(0.2) \pm 1.3 \\
(<0.05-5) \\
\mathrm{n}=14\end{array}$ & $\begin{array}{c}0.2(0.1) \pm 0.2 \\
(<0.05-0.5) \\
\mathrm{n}=9\end{array}$ & $\begin{array}{c}0.2(0.1) \pm 0.1 \\
(<0.05-0.4) \\
\mathrm{n}=17\end{array}$ & $\begin{array}{c}6(2.5) \pm 11 \\
(0.4-39) \\
n=11\end{array}$ & $\begin{array}{c}0.5(0.4) \pm 0.5 \\
(<0.05-2) \\
\mathrm{n}=21\end{array}$ \\
\hline & Kidney & $\begin{array}{c}3.1(2.0) \pm 3.1 \\
(<0.05-12) \\
\mathrm{n}=48\end{array}$ & $\begin{array}{c}4(1) \pm 9 \\
(<0.05-33) \\
n=12\end{array}$ & $\begin{array}{c}1.1(0.5) \pm 1.5 \\
(<0.05-5) \\
n=9\end{array}$ & $\begin{array}{c}1.1(0.8) \pm 1.0 \\
(0.1-3.5) \\
n=15\end{array}$ & $\begin{array}{c}19(14) \pm 17 \\
(238) \\
n=11\end{array}$ & $\begin{array}{c}6(5) \pm 4.5 \\
(<0.05-16) \\
\mathrm{n}=20\end{array}$ \\
\hline & Muscle & $\begin{array}{c}<0.05(<0.05) \\
(<0.05-0.2) \\
\mathrm{n}=51\end{array}$ & $\begin{array}{c}<0.05 \\
(<0.05-0.2) \\
\mathrm{n}=13\end{array}$ & $\begin{array}{c}<0.05 \\
(<0.05) \\
n=9\end{array}$ & $\begin{array}{c}0.1(0.1) \pm 0.3 \\
(<0.05-1.2) \\
\mathrm{n}=15\end{array}$ & $\begin{array}{c}0.1(<0.05) \pm 0.15 \\
(<0.05-0.4) \\
\mathrm{n}=10\end{array}$ & $\begin{array}{c}<0.05 \\
(<0.05-0.8) \\
\mathrm{n}=21\end{array}$ \\
\hline \multirow[t]{3}{*}{$\mathbf{F e}$} & Liver & $\begin{array}{c}1435(1073) \pm 995 \\
(324-4490) \\
\mathrm{n}=49\end{array}$ & $\begin{array}{c}1194(1069) \pm 762 \\
(235-2556) \\
n=14\end{array}$ & $\begin{array}{c}962(927) \pm 461 \\
(349-1826) \\
\mathrm{n}=9\end{array}$ & $\begin{array}{c}1287(1135) \pm 573 \\
(527-2588) \\
n=17\end{array}$ & $\begin{array}{c}1567(1638) \pm 544 \\
(697-2378) \\
n=11\end{array}$ & $\begin{array}{c}1200(1189) \pm 265 \\
(792-1770) \\
n=21\end{array}$ \\
\hline & Kidney & $\begin{array}{c}621(579) \pm 375 \\
(267-2539) \\
n=48\end{array}$ & $\begin{array}{c}499(516) \pm 207 \\
(219-844) \\
n=12\end{array}$ & $\begin{array}{c}914(606) \pm 1091 \\
(425-3808) \\
n=9\end{array}$ & $\begin{array}{c}750(753) \pm 183 \\
(541-1203) \\
n=15\end{array}$ & $\begin{array}{c}819(776) \pm 255 \\
(511-1368) \\
n=11\end{array}$ & $\begin{array}{c}806(786) \pm 250 \\
(489-1681) \\
n=20\end{array}$ \\
\hline & Muscle & $\begin{array}{c}752(775) \pm 246 \\
(262-1204) \\
n=51\end{array}$ & $\begin{array}{c}667(699) \pm 234 \\
(296-1168) \\
n=13\end{array}$ & $\begin{array}{c}467(400) \pm 193 \\
(225-802) \\
n=9\end{array}$ & $\begin{array}{c}544(573) \pm 112 \\
(327-671) \\
n=15\end{array}$ & $\begin{array}{c}651(666) \pm 143 \\
(373-842) \\
n=10\end{array}$ & $\begin{array}{c}584(609) \pm 154 \\
(256-887) \\
n=21\end{array}$ \\
\hline \multirow[t]{3}{*}{$\mathrm{Cu}$} & Liver & $\begin{array}{c}39(30) \pm 38 \\
(9-257) \\
n=49\end{array}$ & $\begin{array}{c}58(36) \pm 49 \\
(20-169) \\
n=14\end{array}$ & $\begin{array}{c}62(30) \pm 77 \\
(18-260) \\
n=9\end{array}$ & $\begin{array}{c}28(25) \pm 16 \\
(15-88) \\
n=17\end{array}$ & $\begin{array}{c}30(31) \pm 11 \\
(13-53) \\
n=11\end{array}$ & $\begin{array}{c}31(24) \pm 31 \\
(12-161) \\
n=20\end{array}$ \\
\hline & Kidney & $\begin{array}{c}17(15) \pm 11 \\
(7-73) \\
n=48\end{array}$ & $\begin{array}{c}15(15) \pm 2 \\
(12-19) \\
n=12\end{array}$ & $\begin{array}{c}16(16) \pm 3 \\
(13-21) \\
\mathrm{n}=9\end{array}$ & $\begin{array}{c}15(13) \pm 6 \\
(11-36) \\
n=15\end{array}$ & $\begin{array}{c}16(15) \pm 4 \\
(11-23) \\
n=11\end{array}$ & $\begin{array}{c}16(16) \pm 4 \\
(10-32) \\
n=20\end{array}$ \\
\hline & Muscle & $\begin{array}{c}7(6) \pm 4 \\
(2-22) \\
\mathrm{n}=51\end{array}$ & $\begin{array}{c}7(7) \pm 2 \\
(3-11) \\
n=13\end{array}$ & $\begin{array}{c}7(7) \pm 2 \\
(4-10) \\
n=9\end{array}$ & $\begin{array}{c}5(5) \pm 1.3 \\
(3-8) \\
n=15\end{array}$ & $\begin{array}{c}5(5) \pm 1.5 \\
(1.8-7) \\
n=10\end{array}$ & $\begin{array}{c}6(7) \pm 2 \\
(2-9) \\
n=21\end{array}$ \\
\hline \multirow[t]{2}{*}{ Se } & Liver & $\begin{array}{c}14(7) \pm 21 \\
(0.6-99) \\
n=37\end{array}$ & $\begin{array}{c}11(7) \pm 11 \\
(1-39) \\
n=13\end{array}$ & $\begin{array}{c}6(6) \pm 3 \\
(2-10) \\
n=8\end{array}$ & $\begin{array}{c}9(7) \pm 7 \\
(3-32) \\
n=14\end{array}$ & $\begin{array}{c}10(7) \pm 8.5 \\
(23-26) \\
n=6\end{array}$ & $\begin{array}{c}14(13) \pm 7 \\
(5-34) \\
n=21\end{array}$ \\
\hline & Muscle & $\begin{array}{c}6(5) \pm 4 \\
(1-21) \\
\mathrm{n}=34 \\
3.8(1.5) \pm 8.5 \\
(0.4-39) \\
\mathrm{n}=20\end{array}$ & nd & nd & nd & nd & $\begin{array}{c}18(15) \pm 9 \\
(2-33) \\
\mathrm{n}=20 \\
1.7(1.4) \pm 1.5 \\
(0.5-5) \\
\mathrm{n}=20\end{array}$ \\
\hline \multirow[t]{3}{*}{$\mathrm{Hg}$} & Liver & $\begin{array}{c}23(5) \pm 66 \\
(0.6-344) \\
n=27\end{array}$ & $\begin{array}{c}14(6) \pm 18 \\
(1-56) \\
n=14\end{array}$ & $\begin{array}{c}4.5(4.1) \pm 3.6 \\
(0.9-12) \\
\mathrm{n}=9\end{array}$ & $\begin{array}{c}22(8) \pm 36 \\
(1-147) \\
n=17\end{array}$ & $\begin{array}{c}16(15) \pm 14 \\
(1.4-44) \\
n=11\end{array}$ & $\begin{array}{c}14(13) \pm 10 \\
(1-32) \\
n=21\end{array}$ \\
\hline & Kidney & $\begin{array}{c}8(3) \pm 13 \\
(0.9-42) \\
n=18\end{array}$ & nd & nd & nd & nd & $\begin{array}{c}7(5) \pm 9 \\
(1-43) \\
n=20\end{array}$ \\
\hline & Muscle & $\begin{array}{c}5(2.4) \pm 7 \\
(0.7-28) \\
n=17\end{array}$ & nd & nd & nd & nd & $\begin{array}{c}2(2) \pm 1.5 \\
(0-5) \\
n=20\end{array}$ \\
\hline
\end{tabular}


Trace metal analyses. After being weighed and dried for $48 \mathrm{~h}$ at $110^{\circ} \mathrm{C}$, liver, kidney and muscle samples were digested in a solution of nitric acid (Merck 456) and slowly heated to $100^{\circ} \mathrm{C}$ until complete digestion was achieved. Atomic absorption spectrophotometry (ARL 3510) was used to determine heavy metal concentrations $(\mathrm{Cu}, \mathrm{Zn}, \mathrm{Cd}, \mathrm{Fe})$. Concentrations are expressed as $\mu \mathrm{g} \mathrm{g}^{-1}$ dry weight (DW).

Parallel to the samples, a set of certified material samples (CRM 278 Community Bureau of Reference, Commission of European Communities) was also analysed to monitor the method's sensitivity. Recoveries ranged from 88 to $102 \%$ for $\mathrm{Cd}, \mathrm{Cu}, \mathrm{Zn}$ and $\mathrm{Fe}$. Limits of detection were $0.01 \mu \mathrm{g} \mathrm{g}^{-1} \mathrm{DW}$ for $\mathrm{Cu}, 0.33$ for $\mathrm{Zn}, 0.16$ for $\mathrm{Fe}$ and 0.22 for $\mathrm{Cd}$. Total $\mathrm{Hg}$ was analysed by flameless atomic absorption spectrophotometry (Perkin-Elmer MAS-50A) after sulphuric acid digestion (Joiris et al. 1991). Se was analysed by fluorimetry following complete digestion of the tissue by nitric, perchloric and hydrochloric acids, coupling to EDTA and 2,3-diaminonaphtalene and extraction by cyclohexane (Mejuto et al. 1987). The fluorimeter was set at an excitation wavelength of $364 \mathrm{~nm}$ and an emission wavelength of $523 \mathrm{~nm}$, with an emission slit of $2 \mathrm{~nm}$ and an integration time for read mode of 2 s. Quality control measurements for total $\mathrm{Hg}$ and Se included replicate analysis resulting in coefficients of variation $<10 \%$ and analysis of certified material (DORM-1 and DORM-2, National Research Council, Canada).

Trace metal concentrations in porpoises from the Norwegian coasts will be presented elsewhere, but have also been included in this study (M. Fontaine et al. unpubl. data).

Stable isotope measurements. After drying at $50^{\circ} \mathrm{C}$ (48 h), samples were ground into a homogeneous powder and treated with a 2:1 chloroform:methanol solution to remove lipids. Carbon dioxide and nitrogen gas were analysed on a V.G. Optima (Micromass) isotope ratio-mass spectrometer (IR-MS) coupled to an N-C-S elemental analyser (Carlo Erba). Routine measurements are precise to $0.3 \%$ for both $\delta^{13} \mathrm{C}$ and $\delta^{15} \mathrm{~N}$. Stable isotope ratios were expressed in delta notation according to:

$$
\delta X=\left[\left(\mathrm{R}_{\text {sample }} / \mathrm{R}_{\text {standard }}\right)-1\right] \times 1000
$$

where $X$ is ${ }^{13} \mathrm{C}$ or ${ }^{15} \mathrm{~N}$ and $\mathrm{R}$ is the corresponding ratio $\left({ }^{13} \mathrm{C} /{ }^{12} \mathrm{C}\right.$ or $\left.{ }^{15} \mathrm{~N} /{ }^{14} \mathrm{~N}\right)$.

Carbon and nitrogen ratios are expressed relative to the V-PDB (Vienna Peedee Belemnite) standard and to atmospheric nitrogen respectively. Reference materials were IAEA CH-6 (sucrose) $\left(\delta^{13} \mathrm{C}=-10.4 \pm 0.2 \%\right.$ ) and IAEA-N1 $\left(\delta^{15} \mathrm{~N}=+0.4 \pm 0.2 \%\right.$ ) respectively.

$\delta^{13} \mathrm{C}$ and $\delta^{15} \mathrm{~N}$ measurements were determined in the muscles of harbour porpoises from Germany, Denmark, Iceland and Norway. Muscle $\delta^{13} \mathrm{C}$ and $\delta^{15} \mathrm{~N}$ data of harbour porpoises from the coasts of northern
France, Belgium and Norway (Das et al. 2003b, M. Fontaine et al. unpubl. data) were integrated to present results.

Data treatment. Statistical analysis of the data was performed using the SAS statistical package (SAS Institute, Version 6.12). Contaminant values were logtransformed to achieve homogeneity of variances and normal distribution. Ordinal logistic regression was performed to examine the relationship between each individual test variable (biometric data, geographical location and trace metal concentrations and stable isotope values in the tissues) and the severity of pathological lesions (emaciation and lesions of the respiratory tract), controlling for all other test variables (see Table 2). The effect of body condition on stable isotope values was investigated using only porpoises from the southern North Sea (France, Belgian and German North Sea coasts) to limit bias linked to natural geographical variations in stable isotopes. Spearman's rank coefficient was used to test relationship between $\mathrm{Hg}$ and $\mathrm{Se}$ and between $\mathrm{Zn}$ and $\mathrm{Cu}$. Multiple linear regressions were used taking into consideration for each individual, $\delta^{13} \mathrm{C}$ and $\delta^{15} \mathrm{~N}$ values, age and metal analyses of the liver and kidney.

Inter-site comparison was realised using ANOVA/ ANCOVA followed by post-hoc Tukey tests. Cd and $\mathrm{Hg}$ comparisons were adjusted for age. Finally, discriminant analysis was used to assess the ability of trace elements (hepatic $\mathrm{Zn}, \mathrm{Cd}, \mathrm{Fe}, \mathrm{Cu}, \mathrm{Se}, \mathrm{Hg}$ ) and stable isotopes (muscle $\delta^{13} \mathrm{C}$ and $\delta^{15} \mathrm{~N}$ ) to discriminate among the different locations (northern France, Belgium, German North Sea, German Baltic Sea, Denmark, Iceland and Norway).

\section{RESULTS}

\section{Pathology and biometric data}

Body mass and blubber thickness decreased significantly with deteriorating body condition, while liver and kidney mass remained constant (Table 2). As a result, the liver mass to body mass ratio increased from 2.4 to $3.9 \%$. This liver to total body mass ratio was not linked to the age or length of the porpoises, making it potentially suitable as a body condition index. In contrast to emaciation, lesions of the respiratory tract (bronchopneumonia) were never associated with body mass, blubber thickness or the liver to body mass ratio (Table 2).

\section{Trace metals, stable isotopes and health status}

Hepatic, renal and muscle Zn concentrations, hepatic $\mathrm{Zn}$ burden and muscle Fe concentrations increased, 







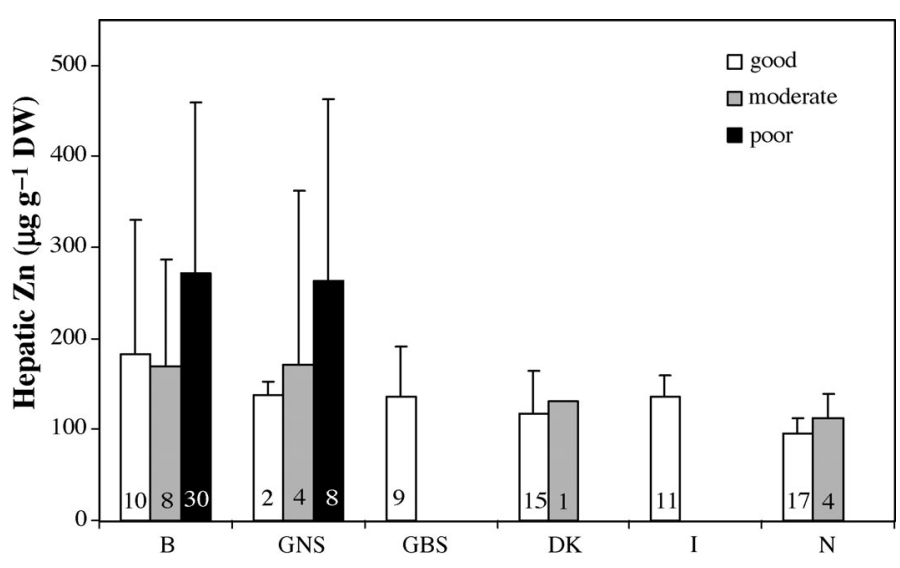

Fig. 1. Phocoena phocoena. Mean $( \pm \mathrm{SD})$ hepatic Zn concentrations in relation to nutritional status (good, moderate, poor) and sampling location. Number of samples shown inside each bar. B: Belgian and French coasts; GNS: German North Sea coasts; GBS: German Baltic coasts; DK: Denmark; I: Iceland; N: Norway

while renal Fe and Se concentrations decreased significantly with deteriorating body condition (Table 2, Fig. 1). $\mathrm{Cu}, \mathrm{Cd}$ and $\mathrm{Hg}$ did not vary significantly between body conditions. Porpoises displaying lesions of the respiratory tract had a higher hepatic Zn burden, higher Fe concentrations and lower $\mathrm{Cu}$ concentrations than porpoises without lung lesions. Muscle $\delta^{13} \mathrm{C}$ and $\delta^{15} \mathrm{~N}$ did not differ from year to year or between seasons; all data were therefore pooled. Stable isotope ratios were similar between porpoises displaying a good, moderate and poor body condition (Table 2, Fig. 2).

A significant relationship was observed between $\mathrm{Zn}$ and $\mathrm{Cu}$ in the liver of harbour porpoises from Norway $\left(\mathrm{R}_{\mathrm{s}}=0.6, \mathrm{p}<0.005\right.$, Fig. 3). This relationship was not observed in the liver of porpoises stranded along the French, Belgian and German coasts $\left(\mathrm{R}_{\mathrm{s}}=0.1, \mathrm{p}<0.3\right.$, Fig. 3). Hepatic Hg was positively correlated with Se $\left(R_{\mathrm{s}}=0.7, \mathrm{p}<0.0001\right)$ and with age $\left(\mathrm{R}_{\mathrm{s}}=0.6, \mathrm{p}<0.0001\right.$ ， Fig. 4).

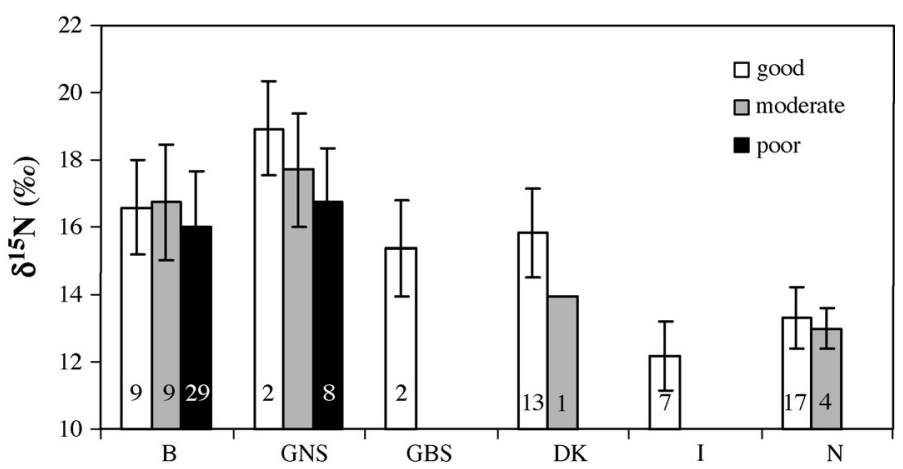

Fig. 2. Phocoena phocoena. Mean $( \pm \mathrm{SD})$ muscle $\delta^{15} \mathrm{~N}$ values in relation to the nutritional status and sampling location. Further details as for Fig. 1

\section{Relationship between stables isotopes and trace metal concentrations}

Multiple linear regressions revealed relationships between muscle $\delta^{15} \mathrm{~N}$ and hepatic and renal $\mathrm{Cd}$ and renal Fe (Table 3, Fig. 5). Weaker relationships were also observed between $\delta^{13} \mathrm{C}$ and renal Se and $\mathrm{Hg}$ (Table 3).

\section{Geographical comparisons and discriminant analyses}

Porpoises from the German North Sea displayed significantly higher $\delta^{15} \mathrm{~N}$ values than porpoises from the coasts of Belgium, Denmark, the German Baltic Sea, Iceland and Norway (ANOVA, $\mathrm{p}<0.001$; Fig. 6). Porpoises from the Belgian and French coasts were significantly enriched in 13-carbon, compared to individuals from Denmark, German Baltic Sea, Iceland and Norway $(\mathrm{p}<0.005)$.
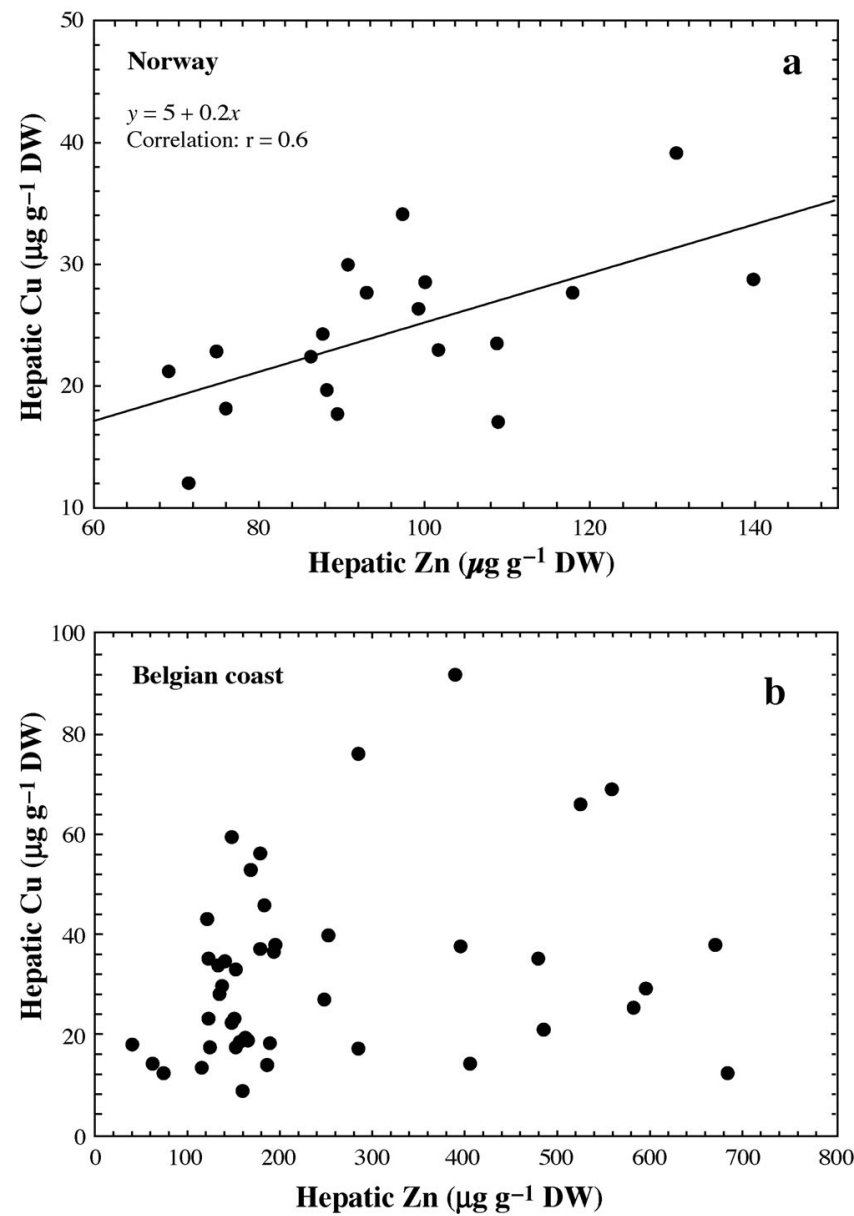

Fig. 3. Phocoena phocoena. Relationship between hepatic Zn and $\mathrm{Cu}$ concentrations in porpoises (a) caught accidentally in fishing nets in Norway and (b) stranded along the Belgian coast 


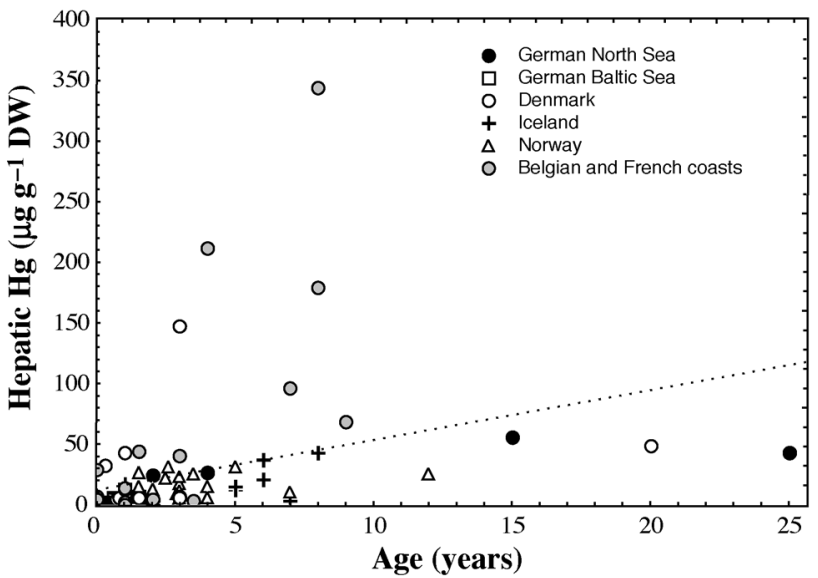

Fig. 4. Phocoena phocoena. Relationship between age (yr) and hepatic $\mathrm{Hg}$

Porpoises from the Belgian and German North Sea coasts displayed higher hepatic Zn concentrations than porpoises from Norway, even when emaciated porpoises were excluded from the test (ANOVA, $p<0.05$; Table 1, Fig. 1). Porpoises from Iceland displayed significantly higher hepatic and renal Cd concentrations than porpoises from Norway, Denmark, the German Baltic Sea and the southern North Sea (ANOVA, $\mathrm{p}<0.05)$. Hepatic $\mathrm{Fe}$ and $\mathrm{Cu}$ levels remained similar between locations. Porpoises from the Belgian and French coasts displayed significantly higher hepatic $\mathrm{Hg}$ concentrations than porpoises from the Baltic Sea (ANCOVA, $F_{5,76}=2.5, \mathrm{p}<0.05$ ).

Site differences were also explored by discriminant analysis to simultaneously evaluate similarities in the concentrations of stable isotopes and 6 hepatic element

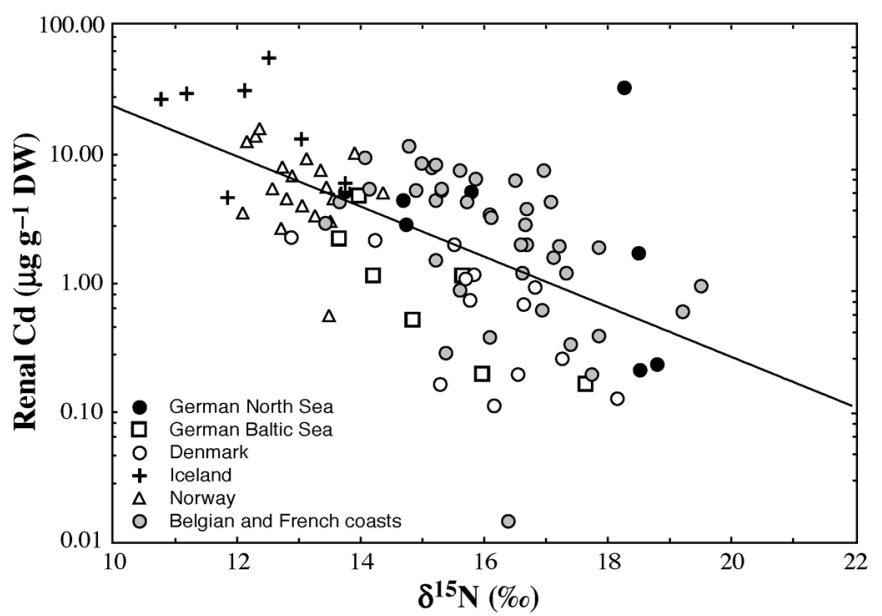

Fig. 5. Phocoena phocoena. Relationship between muscle $\delta^{15} \mathrm{~N}$ and renal $\mathrm{Cd}$ concentrations of harbour porpoises from Northeast Atlantic (log-scale)

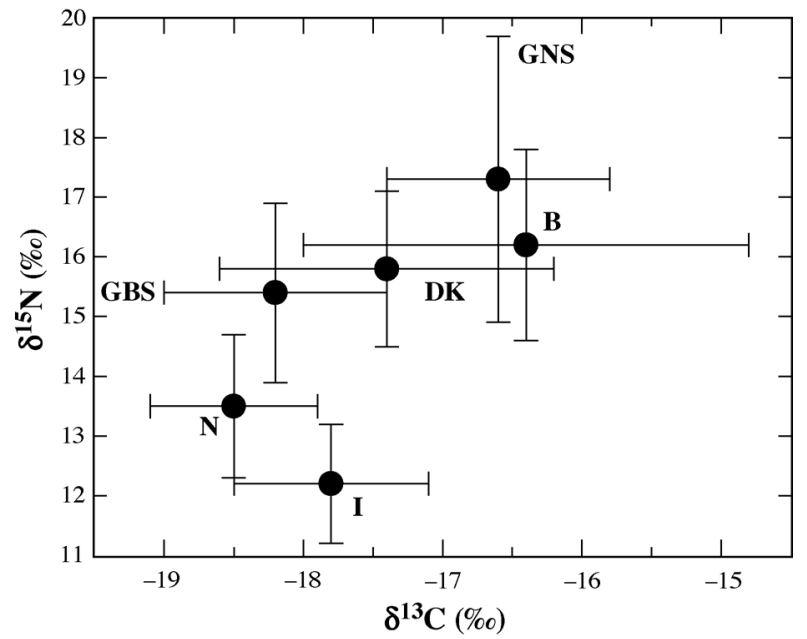

Fig. 6. Phocoena phocoena. Muscle $\delta^{13} \mathrm{C}$ and $\delta^{15} \mathrm{~N}$ values of harbour porpoises from North Sea and adjacent areas. Abbreviations as for Fig. 1

concentrations $\left(\delta^{13} \mathrm{C}, \delta^{15} \mathrm{~N}, \mathrm{Zn}, \mathrm{Cu}, \mathrm{Cd}, \mathrm{Fe}, \mathrm{Se}, \mathrm{Hg}\right)$ among porpoises sampled at the 6 locations (Fig. 7). Discriminant analysis shows how several predefined groups of individuals may be separated, given measurements of several variables. It provides linear functions of the variables that best separate the cases into the predefined groups. We could discriminate 4 porpoise groups discriminated by their $\delta^{15} \mathrm{~N}, \mathrm{Cd}, \delta^{13} \mathrm{C}$ and Zn values (in order of decreasing importance; Fig. 7). The first discriminant function (root) explained $62 \%$ of the variations between groups (Fig. 7). This horizontal axis (Root $1, \delta^{15} \mathrm{~N}$ and $\mathrm{Zn}$ ) discriminated mostly between North Sea (Group IV), Baltic Sea (Group III),

Table 3. Phocoena phocoena. Multiple linear regression analysis (p-values) between muscle $\delta^{13} \mathrm{C}$ and $\delta^{15} \mathrm{~N}$, age (yr), liver to total body mass ratio (\%) and metal concentrations $\left(\mu \mathrm{g} \mathrm{g}^{-1}\right.$ dry wt)

\begin{tabular}{|lcc|}
\hline Parameter & $\delta^{13} \mathrm{C}$ & $\delta^{15} \mathrm{~N}$ \\
\hline Age & 0.3 & 0.2 \\
Liver & & \\
$\mathrm{Zn}$ & 0.7 & 0.1 \\
$\mathrm{Cd}$ & 0.9 & $<0.01$ \\
$\mathrm{Fe}$ & 0.4 & 0.8 \\
$\mathrm{Cu}$ & 0.7 & 0.8 \\
$\mathrm{Se}$ & 0.5 & 0.7 \\
$\mathrm{Hg}$ & 0.2 & 0.1 \\
$\mathrm{Kidney}$ & & \\
$\mathrm{Zn}$ & 0.6 & 0.2 \\
$\mathrm{Cd}$ & 0.6 & $<0.005$ \\
$\mathrm{Fe}$ & 0.5 & 0.4 \\
$\mathrm{Cu}$ & 0.3 & 0.2 \\
$\mathrm{Se}$ & 0.05 & 0.9 \\
$\mathrm{Hg}$ & $<0.05$ & \\
\hline
\end{tabular}




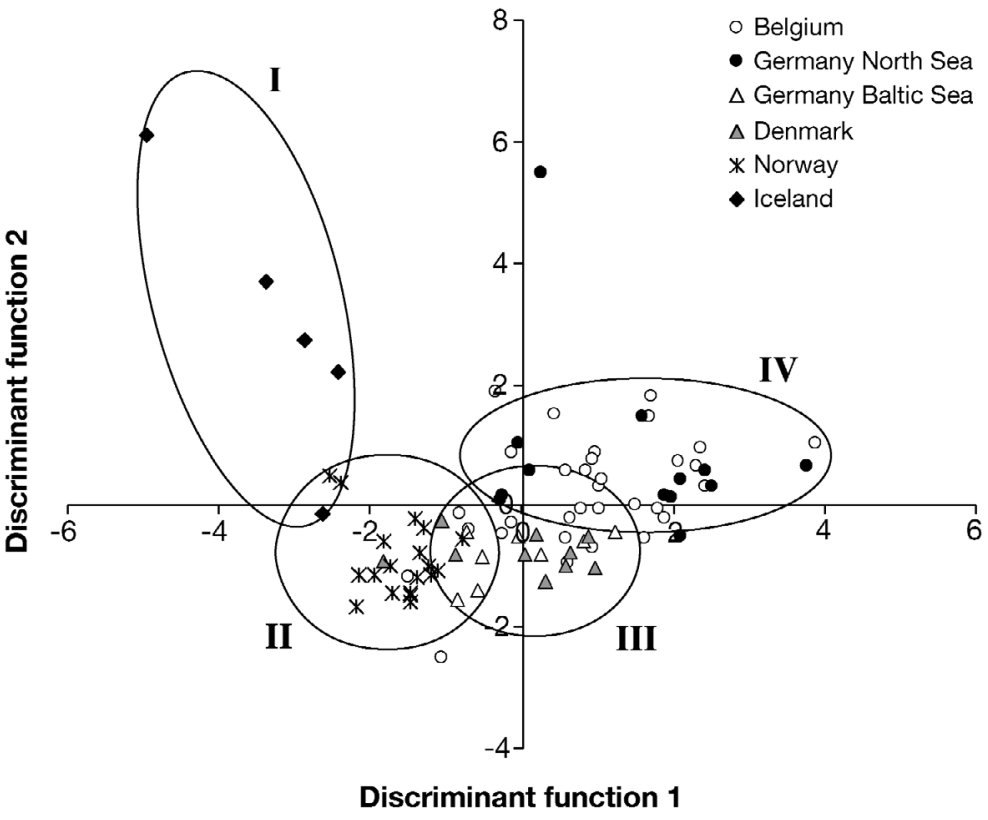

Fig. 7. Phocoena phocoena. Results of discriminant analysis of geographical separation, basis of metal concentrations and stable isotope value $\left(\mathrm{Zn}, \mathrm{Cd}, \mathrm{Fe}, \mathrm{Cu}, \mathrm{Se}, \mathrm{Hg}, \delta^{13} \mathrm{C}\right.$ and $\left.\delta^{15} \mathrm{~N}\right)$ of harbour porpoises. I-IV: 4 groups discriminated (see 'Results')

Norway (Group II) and Iceland (Group I) porpoises. The second discriminant function explained a further $31 \%$ of the variations between groups. This vertical axis (Root 2), reflecting mostly $\mathrm{Cd}$ and $\delta^{13} \mathrm{C}$, discriminated mostly between the North Atlantic, on one side (Groups I and II), and the North and Baltic seas (Groups III and IV) on the other side (Fig. 7). Together, the 2 discriminant functions explained $93 \%$ of the variance. Owing to the highest discriminating value of cadmium, porpoises from Iceland (Group I) are clearly separated from the other locations. Porpoises from Denmark and the German Baltic Sea (Group III) are situated close together in the diagram and could not be discriminated on the basis of their metal and stable isotopes values. Porpoises from Norway (Group II) were clearly discriminated from porpoises from the North Sea (Group IV) by their $\delta^{15} \mathrm{~N}$ and $\mathrm{Zn}$ values.

\section{DISCUSSION}

\section{Body condition of harbour porpoises}

Seasonal changes in body fat condition have already been observed in captive and free-living harbour porpoises, and were correlated with water temperature in relation to the functional role of blubber as insulation and energy reserves (Iverson 2002, Koopman et al. 2002, Lockyer et al. 2003). However, a decrease in blubber thickness can also be linked to emaciation, which is characterised by moderate to severe amyotrophy (Siebert et al. 2001, Jauniaux et al. 2002). The poor nutritional condition of harbour porpoises has been previously related to a reduced food intake linked to parasitic infections (Siebert et al. 1999), ulceration of the upper gastro-intestinal tract or bronchopneumonia (Jauniaux et al. 2002).

In mammals and birds, fasting results in a significant reduction of body and liver mass (Krämer et al. 1993, Debacker et al. 2000, 2001). Liver mass was reduced by two-thirds in experimentally starved rats (Hashimoto et al. 1998) as a result of glycogenolysis and protein catabolism (Krämer et al. 1993). The liver mass of harbour porpoises increased with increasing length (and body mass) of the individuals, but remained strikingly unchanged between porpoises in good, moderate and poor body condition. This means that during the starvation process, blubber lipids and muscle proteins were preferentially metabolised (Markussen 1995). The ratio of liver to total body mass increased significantly with deteriorating body condition as a result of the loss of total body mass (Table 2). As expected, by-catch individuals from Iceland and Norway displayed a better nutritional status than stranded porpoises from the southern North Sea, as evidenced by their higher blubber thickness and lower hepatic to total body-mass ratio. This may reflect the ability of healthy porpoises to mobilize fat from their blubber as primary energy source and spare their protein reserves, while porpoises in poor body condition depend primarily on catabolism of muscle proteins.

\section{Toxicology}

Porpoises from the southern North Sea (northern France, Belgium and German coasts) had the highest $\mathrm{Zn}$ and $\mathrm{Hg}$ burdens compared to porpoises from Norwegian waters and Baltic Sea respectively. These differences may be linked to both a difference in pollutant exposure and nutritional status between individuals. Short-term fasting or prolonged starvation, through decomposition of energy storage and mobilisation of body reserves, are known to influence the metabolism of trace elements such as $\mathrm{Zn}$ or $\mathrm{Cu}$ (Filteau \& Woodward 1982, Spencer et al. 1985, Eisler 1993, Krämer et al. 1993, Debacker et al. 2001). Previous studies have mentioned higher metal and organochlorine levels associated with stranded or debilitated marine mammals compared to individuals displaying good body condition (Jepson et al. 1999, Siebert et al. 1999, Bennet et al. 2001, Anan et al. 2002). The present 
study clearly revealed a general rise in $\mathrm{Zn}$ of the liver, kidney and muscle and Fe of the muscle in harbour porpoises as emaciation progressed, while renal Fe and Se decreased with increasing to emaciation.

In contrast to previous studies (Krämer et al. 1993, Debacker et al. 2000, 2001), the increased concentrations were not linked to a loss of liver (or kidney) mass during emaciation, indicating that metal burdens also increased.

Zn and Hg contamination may lead to a decrease in total body mass of various wild stock or laboratory animals (Eisler 1993, Debacker et al. 2001). Zn and $\mathrm{Hg}$ also exert a critical influence on the mammalian immune system (Salgueiro et al. 2000, Rink \& Gabriel 2001).

Zn absorption from the intestine is known to increase during of malnutrition (Spencer et al. 1985). Adverse biochemical effects of a high $\mathrm{Zn}$ intake on $\mathrm{Cu}$ metabolism have been reported (Spencer et al. 1985, Fosmire 1990). A high Zn intake may cause substantial changes in the $\mathrm{Zn} / \mathrm{Cu}$ ratio in various tissues. In marine mammals, $\mathrm{Zn}$ is generally correlated with $\mathrm{Cu}$ as a result of both antagonistic behaviour and binding to metallothioneins (Anan et al. 2002). In the present study, this relationship was observed for the by-catch porpoises from Norway but not for stranded porpoises from the southern North Sea (France, Belgian and German coasts), reflecting a severe homeostasis disturbance linked to both emaciation and high $\mathrm{Zn}$ concentrations (Fig. 3). Increasing hepatic Zn concentration in harbour porpoises from the Belgian coasts led to an increase in $\mathrm{Zn}$ linked to metallothioneins, but not in $\mathrm{Zn}$ linked to soluble high molecular weight proteins, suggesting that these small proteins involved in metal homeostasis and detoxication may take over the Zn overload resulting from proteolysis (Das 2002). However the question arises as to whether debilitated individuals can still afford the cost of metallothionein synthesis whilst consuming their protein reserves.

Hg was significantly linked to Se, in agreement, with the formation of tiemmanite, well described for marine mammals (Martoja \& Berry 1980, Nigro \& Leonzio 1996). Hg was also linked to age. The Hg levels of the 4 older porpoises were strikingly low, presumably linked to a lower exposure or lower prey intake of these older individuals related to the ageing process (Fig. 4).

As a great proportion of the blubber and muscle mass is lost during emaciation, $\mathrm{Zn}$ and the highly toxic methyl-Hg bound to muscle metalloproteins could also be redistributed in other tissues, such as the liver and kidney, after proteolysis (Spencer et al. 1985, Krämer et al. 1993).

Total and organic Hg were previously associated with the severity of disease of harbour porpoises from German waters, acting as a non-specific morbidity fac- tor (Siebert et al. 1999). Hepatic Zn, Hg, Se and Hg:Se ratio were significantly higher in the porpoises that had died from infectious diseases compared to healthy porpoises that had died from physical trauma (Bennet et al. 2001). The question of whether methyl-Hg concentrations may lead to immunosuppression has been raised (Bennet et al. 2001). In the present study, the increase in $\mathrm{Hg}$ and Se increase with increasingly deteriorating body condition was not significant; however noted that the absence of age data for 46 porpoises very probably weakened the statistical tests. One further (but not contradictory) interpretation is that $\mathrm{Zn}$ and methyl-Hg resulting from blubber and muscle catabolism are redistributed partly to the liver and kidney, leading to a severe metal homeostasis and secondary immunotoxicity.

A combination of high $\mathrm{Zn}$ and $\mathrm{Hg}$ levels and poor body condition could well represent an additional source of stress to porpoises from the southern North Sea, already facing stressful conditions such as elevated levels of organochlorines and other toxic compounds (Jepson et al. 1999, Covaci et al. 2002, Van De Vijver et al. 2003).

Renal Cd concentrations of harbour porpoises increased with increasing age and decreasing $\delta^{15} \mathrm{~N}$ values (Fig. 5). This relationship has also been observed for other marine mammal species from the English Channel and the Irish coast (Das et al. 2003a). Even higher $\mathrm{Cd}$ concentrations were previously measured in harbour porpoises from Greenland (PaludanMüller et al. 1993, Szefer et al. 2002), indicating a south-north increase in Cd concentrations in this species. The relationship suggests that part of the high Cd concentrations measured in the kidneys of harbour porpoises from Iceland and Norway are diet-related resulting from ingestion of $\mathrm{Cd}$-contaminated prey. Indeed, $\mathrm{Cd}$ content has always been high in Arctic sediments and organisms, especially in squids, which are an important dietary item of Greenlander porpoises (AMAP 1998, Bustamante et al. 1998, Dietz et al. 1998, Szefer et al. 2002).

In contrast, hepatic $\mathrm{Zn}, \mathrm{Fe}, \mathrm{Cu}$, Se and $\mathrm{Hg}$ were not associated with stable isotope measurements. This absence of a relationship, especially for $\mathrm{Hg}$, has previously been reported for other marine mammals from the northeast Atlantic (Das et al. 2003a). Relationships between metals and lesions of the respiratory tract were weak, suggesting that other driving factors, such as age and geographic locations, are involved.

\section{Trophic position of harbour porpoises}

Previous studies have documented an increase in the $\delta^{15} \mathrm{~N}$ values of starving animals, as they may use their 
protein reserves for survival (Gannes et al. 1998). In birds, nutritional stress causes substantial increases in diet-fractionation values due either to mobilisation and redeposition of proteins elsewhere in the body or to amino acid composition changes in the tissues (Hobson \& Clark 1992, Gannes et al. 1998). In contrast, in the present study, muscle $\delta^{13} \mathrm{C}$ and $\delta^{15} \mathrm{~N}$ values did not differ among porpoises from the southern North Sea displaying poor, moderate or good body condition. Inability to detect an increase could be linked to lipid extraction prior to isotope analysis of the samples: isotopic change would be expected to be entirely due to the depletion of lipids during starvation. Furthermore, mammals, especially species that experience natural cycles of starvation (i.e. marine or hibernating mammals), may possess biochemical pathways (different from those of birds) in which no additional fractionation of nitrogen occurs (Ben-David et al. 1999). For instance, Arctic ground squirrels Spermophilus parryii plesius in poor and excellent body condition had similar blood $\delta^{15} \mathrm{~N}$ values (Ben-David et al. 1999).

The absence of stable isotope fractionation due to starvation in harbour porpoises makes stable isotope comparisons possible between individuals (including stranded animals) displaying various body conditions.

The $\delta^{15} \mathrm{~N}$ of marine predator tissues is initially determined by the isotopic composition of the phytoplankton and zooplankton sources, technically measured in particulate organic matter (POM). Data may vary as a function of sampling origin, from $4.4 \%$ in some Norwegian fjords to values as high as $9 \%$ in coastal parts of the North Sea (Middelburg \& Nieuwenhuize 1998, Fredrikesen 2003). As a result, part of the $\delta^{15} \mathrm{~N}$ interspecific variation in marine mammals may be related to coastal versus offshore $\delta^{15} \mathrm{~N}$ signatures of the primary producers.

Porpoises from the German Baltic Sea and the Danish and Belgian coasts had similar $\delta^{15} \mathrm{~N}$ values, while $\delta^{13} \mathrm{C}$ varied widely between locations (Fig. 6). According to their $\delta^{15} \mathrm{~N}$ values, porpoises from the German coast occupy a slightly higher trophic position and porpoises from the Norwegian coasts a lower trophic position. The isotope data are in agreement with those from previous studies on the diet of harbour porpoise (Aarefjord et al. 1995, Santos \& Pierce 2003). Several studies in the northeast Atlantic revealed geographical variations in the main prey consumed (reviewed by Santos \& Pierce 2003). Capelin was the most important prey species of harbour porpoises collected off the coast of northern Norway (Aarefjord et al. 1995, Santos \& Pierce 2003). In general, pelagic fishes predominated in the diet of harbour porpoises from the northern areas, whereas benthic species predominated in the diet of individuals from the southern areas (Aarefjord et al. 1995). In the North Sea, the harbour por- poise is known to feed on a wide range of pelagic and demersal fish species such as cod, herring, sole, goby or dab (reviewed by Santos \& Pierce 2003). Expressed as fish biomass, sole and cod represented 41 and $25 \%$ respectively of the stomach content of the harbour porpoises from German waters. In contrast, in the German Baltic Sea, cod can represent $70 \%$ of the dietary biomass of the harbour porpoises (Lick 1991). In the North Sea, cod and sole had higher $\delta^{15} \mathrm{~N}$ values than planktivorous fishes such as sand eels and herrings (Das et al. 2003b).

The depletion in $\delta^{13} \mathrm{C}$ content of individuals from Iceland and Norway could be related to greater offshore feeding, as the continental shelf is considerably reduced along the Icelandic and Norwegian coasts. These results are supported by the high hepatic and renal $\mathrm{Cd}$ concentrations in porpoises from Iceland and Norway which suggest a significant contribution of oceanic and $\mathrm{Cd}$ contaminated prey to their diet.

Trace elements and stable isotopes were able to discriminate porpoises from different locations. However, tissue contaminant burdens are not directly related to genetics, but rather to the migratory and feeding characteristics of the animals (Aguilar 1987). Stable isotopes and metals in harbour porpoises are linked to both food availability and corresponding levels in the prey. Therefore, the possibility that different stocks are mixed in the studied areas cannot be ruled out.

Fine-scale population structure in the eastern North Atlantic has been suggested, and porpoises from the Kattegat and Skagerrak have been found to be genetically different from those from the west coasts of Norway. Porpoises from Iceland have been found to be genetically closer to western populations (west Greenland, Gulf of St. Lawrence, Newfoundland, Gulf of Maine) than to Norwegian populations (Tolley et al. 2001). This difference probably results from isolating events caused by repeated range contractions and expansions throughout Quaternary glaciations events within the North Atlantic. Our results suggest that ecological separation of porpoises occurs in the Northeast Atlantic, enhancing genetic separations of the stocks.

In summary, heavy metal absorption depends on a variety of factors often directly related to the metabolism and physiology of the animal concerned. Harbour porpoises from the North Sea displayed wide variations linked to geographic location, nutritional status, age and diet. Zn, Fe and Se concentrations were clearly linked to emaciation and lesions of the respiratory system. In addition, the unchanged liver mass and concomitant increase in the hepatic Zn load during emaciation indicate a specific metabolism during starvation, which differs from that of other mammals. Although facing limited toxicological risk when in normal healthy condition, with deteriorating body condi- 
tion, the porpoises could well be adversely affected by $\mathrm{Zn}$ and $\mathrm{Hg}$. The observed relationship between $\mathrm{Cd}$ levels and stable isotopes for harbour porpoises and other species suggests that such variations are dietrelated and that porpoises have local specific diets throughout their distribution area.

Further investigations are needed before we can reach any definite conclusions, but we cannot reject the hypothesis that trace metal exposure may influence marine mammal health status, and may thus have contributed to the high mortality rates in the past few years. Hence, stable isotope and contaminant analyses, together with traditional approaches (genetic and morphological), could provide valuable information on the population biology of harbour porpoises in the Northeast Atlantic.

Acknowledgements. The authors are grateful to G. Vikingsson (Marine Research Institute, Iceland) and K. Tolley (University of Stellenbosch, South Africa) for providing facilities for porpoise sampling in Iceland and Norway. Thanks to J. Tavernier and J. Haelters (Management Unit of the North Sea Mathematical Models, Belgium), C. Brenez, the Ceto-Club (Liège University, Belgium) and the Centre de Recherche sur les Mammifères Marins (La Rochelle, France) for sampling along the Belgian and French coasts. Thanks to A. Albert and L. Seidel (Liège University, Belgium) for statistical treatment and to R. Bouhy, R. Biondo, G. Lepoint and P. Dauby (Liège University, Belgium) for useful advice and help concerning stable isotope measurements. Thanks to C. Lockyer (Age Dynamics, Kongens Lyngby, Denmark) and E. Rogan (University College Cork, Ireland) for age determination of the porpoises. This manuscript was greatly improved by the comments of 4 anonymous reviewers. Thanks to A. Gilles (FTZWestküste, Germany) and P. Smith (Liège University, Belgium) for correcting the manuscript. K.D. received grants from the 'Fonds pour la Recherche dans l'Agriculture et l'Industrie' (FRIA) and Marie-Curie Fellowship (EVK3-CT-200250009). Parts of this were funded by the Belgian Office for Scientific, Technical and Cultural Affairs (contract MN/DD/50 and EV/XX/804). This paper is a MARE publication 044.

\section{LITERATURE CITED}

Aarefjord H, Bjørge AJ, Kinze CC, Lindstedt I (1995) Diet of harbour porpoises (Phocoena phocoena) in Scandinavian waters. Rep Int Whal Comm Spec Issue 16:211-222

Abend AG, Smith TD (1995) Differences in ratios of stable isotopes of nitrogen in long-finned pilot whales (Globicephala melas) in the western and eastern North Atlantic. ICES J Mar Sci 52:837-841

Aguilar A (1987) Using organochlorine pollutants to discriminate marine mammal populations: a review and critique of the methods. Mar Mamm Sci 3:242-262

Aguilar A, Borrell A (1994) Abnormally high polychlorinated biphenyl levels in striped dolphins (Stenella coeruleoalba) affected by the 1990-1992 Mediterranean epizootic. Sci Total Environ 154:237-247

AMAP (Artic Monitoring and Assessment Programme) (1998). AMAP Assessment Report: Arctic Pollution Issues. AMAP Secretariat, Oslo

Anan Y, Kunito T, Ikemoto T, Kubota R, Wanatabe I, Tanabe
S, Miyazaki N, Petrov EA (2002) Elevated concentrations of trace elements in Caspian seals (Phoca caspica) found stranded during the mass mortality events in 2002. Arch Environ Contam Toxicol 42:354-362

Ben-David M, McColl CJ, Boonstra R, Karels TJ (1999) ${ }^{15} \mathrm{~N}$ signatures do not reflect body condition in Arctic ground squirrels. Can J Zool 77:1373-1378

Bennet PM, Jepson PD, Law RJ, Jones BR, Kuiken T, Baker JR, Rogan E, Kirkwood JK (2001) Exposure to heavy metals and infectious disease mortality in harbour porpoises from England and Wales. Environ Pollut 112:33-40

Burns JM, Trumble SJ, Castellini MA, Testa JW (1998) The diet of Weddel seals in McMurdo Sound, Antarctica as determined from scat collections and stable isotope analysis. Polar Biol 19:272-282

Bustamante P, Caurant F, Fowler SW, Miramand P (1998) Cephalopods as a vector for the transfer of cadmium to top marine predators in the north-east Atlantic ocean. Sci Total Environ 220:71-80

Caurant F, Amiard JC, Amiard-Triquet C, Sauriau PG (1994) Ecological and biological factors controlling the concentrations of trace elements ( $\mathrm{As}, \mathrm{Cd}, \mathrm{Cu}, \mathrm{Hg}, \mathrm{Se}, \mathrm{Zn}$ ) in delphinids Globicephala melas from the North Atlantic Ocean. Mar Ecol Prog Ser 103:207-219

Covaci A, Van de Vijver K, Decoen W, Das K, Bouquegneau JM, Blust R, Schepens P (2002) Determination of organohalogenated contaminants in liver of harbour porpoises (Phocoena phocoena) stranded on the Belgian coast. Mar Pollut Bull 44:1152-1169

Das K (2002) Trace metal contamination and detoxication processes in marine mammals from European coasts. $\mathrm{PhD}$ thesis, Université de Liège, Liège

Das K, Lepoint G, Loizeau V, Debacker V, Dauby P, Bouquegneau JM (2000) Tuna and dolphin associations in the North-East Atlantic: evidence of different ecological niches from stable isotope and heavy metal measurements. Mar Pollut Bull 40:102-109

Das K, Debacker V, Pillet S, Bouquegneau JM (2002) Heavy metals in marine mammals. In: Vos JG, Bossart G, Fournier M, O'Shea $\mathrm{T}$ (eds) Toxicology of marine mammals, Taylor \& Francis, Washington DC, p 135-167

Das K, Beans C, Holsbeek L, Mauger G, Berrow SD, Rogan E, Bouquegneau JM (2003a) Marine mammals from Northeast Atlantic: evaluation of their trophic position by $\delta^{13} \mathrm{C}$ and $\delta^{15} \mathrm{~N}$ and influence on their trace metal concentrations. Mar Environ Res 56:349-365

Das K, Lepoint G, Leroy Y, Bouquegneau JM (2003b) Marine mammals from the southern North Sea: insights in their feeding ecology from $\delta^{13} \mathrm{C}$ and $\delta^{15} \mathrm{~N}$ measurements. Mar Ecol Prog Ser 263:287-298

Debacker V, Jauniaux T, Coignoul F, Bouquegneau JM (2000) Heavy metal contamination and body condition of wintering guillemots (Uria aalge) at the Belgian coast from 1993 to 1998. Environ Res 84:310-317

Debacker V, Rutten A, Jauniaux T, Daemers C, Bouquegneau JM (2001) Combined effects of experimental heavy-metal contamination $(\mathrm{Cu}, \mathrm{Zn}$, and $\mathrm{Ch} 3-\mathrm{Hg})$ and starvation on quail's body condition. Parallelism with a wild common guillemot population found stranded at the Belgian coasts. Biol Trace Elem Res 87:82-107

De Guise S, Martineau D, Béland P, Fournier M (1995) Possible mechanisms of action of environmental contaminants on St. Lawrence beluga whales (Delphinapterus leucas). Environ Health Perspect 103:73-77

De Swart RL, Ross PS, Timmerman HH Vedder LJ and 6 others (1994) Impairment of immune function in harbor 
seals (Phoca vitulina) feeding on fish from polluted waters. Ambio 23:155-159

Dietz R, Nørgaard J, Hansen JC (1998) Have arctic mammals adapted to high cadmium levels? Mar Pollut Bull 36: 490-492

Eisler R (1993) Zinc hazards to fish, wildlife and invertebrates: a synoptic review. US Contam Hazard Rev Report 26:106

Filteau SM, Woodward B (1982) The effect of severe protein deficiency on serum zinc concentration on mice fed requirement level or a very high level of dietary zinc. J Nutr 112:1974-1977

Fosmire GJ (1990) Zinc toxicity. Am J Clin Nutr 51:225-227

Fredrikesen S (2003) Food web studies in a Norwegian kelp forest based on stable isotope $\left(\delta^{13} \mathrm{C}\right.$ and $\left.\delta^{15} \mathrm{~N}\right)$ analysis. Mar Ecol Prog Ser 260:71-78

Gannes LZ, Del Rio CM, Koch P (1998) Natural abundance variations in stable isotopes and their potential uses in animal physiological ecology. Comp Biochem Physiol A 119: 725-737

Hashimoto PH, Goami Y, Yoneda K, Mori K and 5 others (1998) Fine structure of rat liver, adrenal, testis and seminal vesicle in experimental emaciation. J Electron Microsc 47:251-262

Hobson KA, Clark RG (1992) Assessing avian diets using stable isotopes. II: factors influencing diet-tissue fractionation. Condor 94:189-197

Hobson KA, Welch HE (1992) Determination of trophic relationships within a high Arctic food web using $\delta^{13} \mathrm{C}$ and $\delta^{15} \mathrm{~N}$ analysis. Mar Ecol Prog Ser 84:9-18

Hobson KA, Ambrose WG, Renaud PE (1995) Sources of primary production, benthic-pelagic coupling, and trophic relationships within the northeast water polynia: insights from $\delta^{13} \mathrm{C}$ and $\delta^{15} \mathrm{~N}$ analysis. Mar Ecol Prog Ser 128:1-10

Hobson KA, Schell D, Renouf D, Noseworthy E (1996) Stable carbon and nitrogen isotopic fractionation between diet and tissues of captive seals: implications for dietary reconstructions involving marine mammals. Can J Fish Aquat Sci 53:528-533

Hyvärinen H, Sipilä T (1984) Heavy metals and high pup mortality in the Saimaa ringed seal population in Eastern Finland. Mar Pollut Bull 15:335-337

Iverson SJ (2002) Blubber. In: Perrin WF, Würsig B, Thewissen JGM (eds) Encyclopedia of marine mammals. Academic Press, San Diego, CA, p 107-112

Jauniaux T, Petitjean D, Brenez C, Borrens M, Brosens L, Haelters J, Tavernier J, Coignoul F (2002) Post-mortem findings and causes of death of harbour porpoises (Phocoena phocoena) stranded from 1990 to 2000 along the coastlines of Belgium and Northern France. J Comp Pathol 126:243-253

Jepson PD, Bennet PM, Allchin CR, Law RJ, Kuiken T, Baker JR, Rogan E, Kirkwood JK (1999) Investigating potential associations between chronic exposure to polychlorinated biphenyls and infectious disease mortality in harbour porpoises from England and Wales. Sci Total Environ 243/244:339-348

Joiris CR, Holsbeek L, Bouquegneau JM, Bossicart M (1991) Mercury contamination of the harbour porpoise Phocoena phocoena and other cetaceans from the North Sea and the Kattegat. Water Air Soil Pollut 56:283-293

Kelly JF (2000) Stable isotopes of carbon and nitrogen in the study of avian and mammalian trophic ecology. Can J Zool 78:1-27

Kidd KA, Hesslein RH, Fudge RJP, Hallard KA (1995) The influence of trophic level as measured by $\delta^{15} \mathrm{~N}$ on mercury concentrations in freshwater organisms. Water Air Soil Pollut 80:1011-1015
Koopman HN, Pabst DA, McLellan WA, Dillaman RM, Read AJ (2002) Changes in blubber distribution and morphology associated with starvation in the harbour porpoise (Phocoena phocoena). Physiol Biochem Zool 75:498-512

Krämer K, Markwitan A, Menne A, Pallauf J (1993) Zinc metabolism in fasted rats. J Trace Elem Electrolytes Health Dis 7:141-146

Kuiken T, Hartmann MG (1993) Proceedings of the first ECS workshop on cetacean pathology dissection techniques and tissue sampling. Proceedings of the European Cetacean Society, Leiden

Law RJ (1996) Metals in marine mammals. In: Beyer WN, Heinz GH, Redmond-Norwood AW (eds) Environmental contaminants in wildlife. Interpreting tissues concentrations. SETAC Spec Publ Ser. CRC Press, Boca Raton, FL, p 357-376

Lesage V, Hammil MO, Kovacs KM (2001) Marine mammals and the community structure of the estuary and gulf of St. Lawrence, Canada: evidence from stable isotope analysis. Mar Ecol Prog Ser 210:203-221

Lick RR (1991) Parasites from the digestive tract and food analysis of harbour porpoise Phocoena phocoena from German coastal waters. Eur Res Cetaceans 5:65-68

Lockyer C (1995) A review of factors involved in zonation in odontocetes teeth, and an investigation of the likely impact of environmental factors and major life events on harbour porpoise tooth structure. In: Bjorge A, Donovan GP (eds) Biology of the phocoenids. International Whaling Commission, Cambridge, p 511-529

Lockyer C, Desportes G, Hansen K, Shephard G, Labberté S, Siebert U (2003) Monitoring growth and energy utilisation of harbour porpoise in human care. In: Hauge T, Desportes G, Vikingsson GA, Witting L (eds) Harbour porpoises in the North Atlantic. Scientific Publications 5. The North Atlantic Marine Mammal Commission, Tromsø, p 107-120

Markussen (1995) Changes in metabolic rate and body composition during starvation and semistarvation in harbour seals. In: Blix AS, Walloe L, Ulltang O (eds) Developments in marine biology. Whales, seals, fish and man, Vol 4. Elsevier, Amsterdam, p 383-391

Martoja R, Berry JP (1980) Identification of tiemannite as a probable product of demethylation of mercury by selenium in cetaceans. A complement to the scheme of the biological cycle of mercury. Vie Milieu 30:7-10

Mejuto CM, Bollain MH, Rodriguez I, Martinez FB (1987) Fluorimetric determination of selenium in human tissues. Analusis 15:420-423

Michener RH, Schell DM (1994) Stable isotope ratios as tracers in marine aquatic food webs. In: Lattjha $\mathrm{K}$, Michener $\mathrm{RH}$ (eds) Stable isotopes in ecology and environmental science, Blackwell Scientific Publications, Oxford, p 138-186

Middelburg JJ, Nieuwenhuize J (1998) Carbon and nitrogen stable isotopes in suspended matter and sediments from the Schelde estuary. Mar Chem 60:217-225

Nigro M, Leonzio C (1996) Intracellular storage of mercury and selenium in different marine vertebrates. Mar Ecol Prog Ser 135:137-143

Paludan-Müller P, Agger CT, Dietz R, Kinze CC (1993) Mercury, cadmium, zinc, copper and selenium in harbour porpoise (Phocoena phocoena) from west Greenland. Polar Biol 13:311-320

Reijnders PJH (1986) Reproductive failure in common seals feeding on fish from polluted coastal waters. Nature 324: 456-457

Reijnders PJH, Aguilar A (2002) Pollution and marine mammals. In: Perrin WE, Würsig B, Thewissen JGM (eds) Encyclopedia of marine mammals. Academic Press, San Diego, CA, p 948-957 
Rink L, Gabriel P (2001) Extracellular and immunological actions of zinc. Biometals 14:367-383

Salgueiro MJ, Zubillaga M, Lysionek A, Cremaschi G and 6 others (2000) Zinc status and immune system relationship. A review. Biol Trace Elem Res 76:193-205

Santos MB, Pierce GJ (2003) The diet of harbour porpoise (Phocoena phocoena) in the Northeast Atlantic. Oceanogr Mar Biol Annu Rev 41:355-390

Siebert U, Joiris C, Holsbeek L, Benke H, Failing K, Frese K, Petzinger E (1999) Potential relation between mercury concentrations and necropsy findings in cetaceans from German waters of the North and Baltic Seas. Mar Pollut Bull 38:285-295

Siebert U, Wunschmann R, Weiss R, Frank H, Benke H, Frese K (2001) Post-mortem findings in harbour porpoises (Phocoena phocoena) from the German North and Baltic Seas. J Comp Pathol 124:102-114

Smith RJ, Hobson KA, Koopman HN, Lavigne DM (1996) Distinguishing between populations of fresh- and salt-water harbour seals (Phoca vitulina) using stable-isotope ratios

Editorial responsibility: Otto Kinne (Editor), Oldendorf/Luhe, Germany and fatty acid profiles. Can J Fish Aquat Sci 53:272-279 Spencer H, Kramer L, Osis D (1985) Zn metabolism in man. J Environ Pathol Toxicol Oncol 86:864-867

Szefer P, Zdrojewska I, Jensen J, Lockyer C, Skora K, Kuklik I, Malinga M (2002) Intercomparison studies on distribution and co-associations of heavy metals in liver, kidney and muscle of harbor porpoises Phocoena phocoena from southern Baltic Sea and coastal waters of Denmark and Greenland. Arch Environ Contam Toxicol 42:508-522

Tolley K, Vikingsson G, Rosel PE (2001) Mitochondrial DNA sequence variation and phylogeographic patterns in harbour porpoises (Phocoena phocoena) from the North Atlantic. Conserv Genetics 2:349-361

Van De Vijver KI, Hoff PT, Das K, Van Dongen W, Esmans EL, Bouquegneau JM, Blust R, De Coen WM (2003) Perfluorinated chemicals infiltrate deepest ocean waters: link between exposure levels and stable isotopes ratios in marine mammals. Environ Sci Technol 37:5545-5550

Zelikoff JT, Thomas PT (1998) Immunotoxicology of environmental and occupational metals. Taylor \& Francis, London

Submitted: August 11, 2003; Accepted: May 4, 2004 Proofs received from author(s): October 6, 2004 